\title{
A Study of Aging and Love in "The Bear Came over the Mountain"
}

\author{
Ping Wei ${ }^{1}$, Yu Tang ${ }^{2}$ \\ ${ }^{1}$ School of Foreign Languages, Southwest University, Chongqing, China \\ ${ }^{2}$ School of Culture and Social Development Studies, Southwest University, Chongqing, China \\ Email: weiping@swu.edu.cn, ty69@swu.edu.cn
}

Received 3 March 2015; accepted 26 March 2015; published 27 March 2015

Copyright (C) 2015 by authors and Scientific Research Publishing Inc.

This work is licensed under the Creative Commons Attribution International License (CC BY). http://creativecommons.org/licenses/by/4.0/

(c) (i) Open Access

\begin{abstract}
Alice Munro, Canadian author and winner of the Nobel Prize for Literature in 2013, has written a number of short stories. Her short story, "The Bear Came over the Mountain", circles around an old couple, Grant and Fiona. The story tells of an evolution of love under the background of aging. The love and aging interweave and collide with each other to generate the great theme of the story-love evolves with time and it will finally defeat aging. This paper attempts to analyze the components and structure of love at different stages and illustrate how love evolves in time and how it survives the battle against aging.
\end{abstract}

Keywords

"Bear Came over the Mountain", Aging, Love

\section{Introduction}

Alice Munro, a Canadian short-story writer, won the Nobel Prize for Literature in 2013, which has a significant meaning for both Canadian literature and the short-story circle. Her fiction has also earned other recognitions including three Governor-General's awards and two Giller Prizes.

Munro’s short story “The Bear Came over the Mountain”, from her 2001 collection Hateship, Friendship, Courtship, Loveship, Marriage, tells of a marriage that goes through different stages of life. With Munro’s sure command of detail, pace, and the incremental revelation of past incidents, it gradually becomes an incredibly powerful examination of betrayal and the many varieties of love (Holcombe, 2013: p. 25). James Wood praises it as “one of Munro’s finest stories” (Wood, 2013: p. 9). The story has been adapted into a movie called Away from Her by Sara Polley.

In "The Bear Came over the Mountain”, Munro interweaves love with time and aging and leads us through a journey of aging. With the progress of time, Fiona and Grant's love goes through different stages without falling 
apart. In this paper, we attempt to illustrate how love evolves in time and how it survives the battle against aging.

\section{Literature Review}

There are few researches dealing with the story "The Bear Came over the Mountain” directly. Muhammad Chowdhury describes it as "a story of love, romantic affairs, family relationship, enigma of romance and psychological disorientation" (Chowdhury, 2013). In review of "The Bear Came over the Mountain”, Bronwyn Drainie praises Munro's expertise at plotting, with surprising (yet totally plausible) twists on every page (Drainie, 2001: p. 336).

As a writer of modern realism and short story, Munro's unique writing style has attracted wide attention in the literary world. Bosmans describes her fiction as having revolutionized the architecture of short stories, especially in its tendency to move forward and backward in time (Bosmans, 2013: p. 16). Mona Simpson compares Munro to Chekov, "Her genius, like Chekhov's, is quiet and particularly hard to describe, because it has the simplicity of the best naturalism, in that it seems not translated from life but, rather, like life itself”.

Many critics deem Munro's writing distinctive in that she applies multiple visions in her writing. She is good at slicing reality into many layers. As Martin states in the introduction of his book Alice Munro: Paradox and Parallel:

Her art is a complex counterpointing of opposed truths in a memorable model of life and reality. One of this doubleness, or reciprocation, might be put like this: in vivid images and dramatic scenes she presents, and makes real and convincing, concepts that we usually couch in abstract terms, cliches, and wordy description. Conversely, she charges common and familiar incidents with surprising meanings and dimensions. Adapting the terms Alice Munro herself used in the Weekend Magazine of 11 May 1794, one might say that she makes "the mysterious touchable" and "the touchable mysterious" (Martin, 1987: p. 1).

Ajay Heble suggests that the understanding of Munro's text and depends not only on what happens in the fiction, but also on what might have happened (Heble, 1994: p. 208). Munro presents a dimension of strangeness and mystery that throws everyday reality into question and reshapes it into another less definable yet more truthful reality (Mazur \& Cathy, 2007: p. 5). If her story is compared to a house, Munro encourages her readers to explore what's out there, and to reach beyond the boundaries.

There has been few researches on Alice Munro's works in China. In her paper, Lin Yuzhen analyzes how Munro deals with the multiple themes such as "emotion," "life," "wilderness" and "feminism" so as to explain why Alice Munro, who is good at writing realist stories from a feminist perspective, could rise above internationally in an era when the post-modernist writing prevails in the literary world (267). She describes Munro's works as "utilizing simple narratives to explore profound truth of a lifetime” (Lin, 2006: p. 267).

\section{The Course of Aging}

\subsection{Young Age: Fatuous Love}

Grant and Fiona's love starts off when they are young and vigorous. At this stage, their love is governed by passion. They both have strong feelings of love and desire for each other. This love is full of newness and excitement. The newness they feel is largely due to the differences in their backgrounds. Fiona is amused by Grant's small town phrases and she likes to "drolly repeat them" (Munro, 1989: p. 274). Young Fiona is a saucy girl who likes to play jokes.

Grant is so fascinated with Fiona that "he never wanted to be away from her” (Munro, 1989: p. 274). He appreciates her personality, and thinks that "She had the spark of life".

In fact, both of them are eager to go into wedlock.

"Do you think it would be fun-" Fiona shouted.

"Do you think it would be fun if we got married?"

He took her up on it, he shouted yes. He wanted never to be away from her. She had the spark of life (Munro, 274).

"Fun" is used by Fiona to picture her future marriage, which indicates that she associates love more with excitement. "Shouted" implies Grant's eagerness and zeal to spend his life with Fiona.

Love comes like a whirlwind, and passion leads Grant and Fiona to make a life-long commitment. At young 
age, they feel that infinity is within their grasp.

\subsection{Middle Age: Empty Love}

However, passion is not enough for long term preservation of love and marriage. Real marriage life isn’t all about "fun". Time gradually erodes their passion.

Passionate love diminishes as the positive force of the relationship is taken over by opposite forces. In Grant and Fiona's cases, the most violent force striking their relationship is the enticement of other women. During the years he works as a professor, Grant comes in touch with waves of other women. Grant begins to feel dissatisfaction and look for that passionate love once again outside the marriage. Munro discloses Grant's drifting away from marriage in a psychological description:

He appreciated as never before a pageant of torn clouds and winter sunset seen from his office window, the charm of antique lamps glowing between his neighbors' living-room curtains, the cries of children in the park at dusk, unwilling to leave the hill where they'd been tobogganing (Munro, 301).

The scenes at a distance seem more beautiful to Grant than the one surrounds him. As a saying goes, "grass at the other side of the mountain is always greener." Grant, like the children playing on the hill, is unwilling to return home.

Grant wanders off to the other side of marriage and explores other possibilities. With other women, Grant feels "tender intimations of feeling required were out the window" (Munro, 310). The intimacy between Grant and Fiona also decreases. While Grant plays in the minefield of love affairs and feels a gigantic increase in wellbeing, Fiona is left out by him. When Grant is enjoying himself in the playfield of women, Fiona's mother is on the edge of dying. Grant fails to cater to Fiona's psychological needs and leaves her licking her own wounds. Even though he has never been away from her for a single night, their psychological distance is widening. Their marriage now is an empty shell supported merely by commitment. Fiona feels more exhausted than ever and longs for a "new life" (Munro, 284).

\subsection{Retiring Age: Companionate Love}

Words about Grant's affairs with students get around. Luckily, before things turns worse, Grant steers his life back on track and saves his marriage in time. He takes an early retirement with reduced pension. And the couple moves to a farmhouse in the countryside.

At this stage, their marriage also takes a good turn, for there is no more diversion for Grant. "There were no more hectic flirtations. No bare female toes creeping up under a man's pants leg at a dinner party. No more loose wives” (Munro, 295).

Their love is no longer passionate but more steady. Grant is now able to give Fiona more company. They work on the house and go cross-country skiing together. They also make trips to foreign countries like Greece and Australia; they develop similar habits and even laugh at same things; they watch quite a lot of TV together. "They had spied on the lives of every beast or reptile or insect or sea creature that a camera was able to reach, and they had followed the plots of what seemed like dozens of rather similar fine nineteenth-century novels” (Munro, 281). By disclosing the astonishing amount of programs they watch together, Munro accentuates the great length of time they have spent together.

"Their time of liveliest intimacy", is when they have their daily conversations before supper (Munro, 292). They talk about their work, reading, and what they have been thinking in a close but separate day. This is more of a psychological intimacy. They have developed a special closeness and connectedness over a long time. Even though there is "the five or ten minutes of physical sweetness", sexual desire is no longer an important part of their life.

Companionate love is governed by intimacy and unwavering commitment. They have developed a deep attachment and spiritual connection. And their time together is full of tenderness and humor. There's serenity about their love, without many ups and downs. Love enduring a long time is like still water that runs long.

\subsection{Old Age: Renewed Love amid Loss}

\subsubsection{Grant's Realization}

However, Fiona’s degenerative disease breaks the serenity of their life. While Fiona loses her memories, Grant 
faces the threat of losing Fiona. However, his sense of crisis may have relighted the Grant's passion towards Fiona.

As a saying goes, "Absence makes the heart grow fonder.” During Fiona’s first thirty days in Medowlake, no visit is allowed. It is at this time that Grant is reminded of his deep affection for Fiona. He feels that it was the longest month of his life. It is longer than the month when Jaqui (his lover) was away on holiday at the beginning of their affair. He often pictures Fiona in the old shabby Medowlake. He worries so much about her that he phones Medowlake everyday. His constancy amuses Kristy (the nurse there).

It is evident that Grant misses Fiona intensely. Grant is enveloped by solitude without Fiona by his side, for Fiona has wholly integrated into his life over the years. Everything he does, each object in the house is a reminder of Fiona. He even wonders about what program Fiona was watching in Medowlake. And he recalls the numerous television programs they have watched together. "He went skiing alone and counted the times he went around the field" (Munro, 282). The white vast wildness of the open field in a cold winter forms a strong contrast with Grant's lonely profile. When Grant comes back to the darkening house, loneliness takes over him completely. The house harbors their liveliest intimacies. Their love has already deeply rooted in this house.

Moreover, guilt from the past keeps torturing Grant while he's alone. Munro allows readers to look into Grant's inner world by vividly depicting his dream. In Grant's dream, a girl student who he had an affair with earlier commits suicide. There are "a flock of cold-eyed young women all in black robes, all in mourning, who never took their bitter stares off him" (Munro, 293). Fear nearly suffocates him like a "thickening black ring" (Munro, 293). Fiona plays a reassuring role in his dream. She is "untroubled" and tries to consol Grant. Grant is reminded of the way she used to be at a party, retiring into her own corner and "holding out against the tide", "as if chastity was chic, and reticence a blessing” (293). Here Munro implies that Fiona has always remained loyal to their love. His lovers have all turned their back on him, but Fiona is always there for him. Fiona's chastity makes Grant more shameful. He is determined to make up for his past and take good care of Fiona.

\subsubsection{Grant's Redemption}

With renewed affection and the realization of his attachment to Fiona, Grant makes painstaking efforts to maintain their relationship and look after Fiona. It is Grant's compensation for his absence in earlier stages of marriage, and also his attempt to redeem his guilt.

After thirty days of separation from Fiona, Grant is eager to pay her his first visit. This is the beginning of his redemption, for he does everything with renewed affection for Fiona. "He woke up early, and was full of a solemn tingling. He felt a expectation of discovery" (Munro, 287). He now buys flowers for Fiona, which is something he has never done before. But when Grant finally gets to see Fiona, their meeting turns out awkward as Fiona doesn't seem to recognize him. Moreover, Fiona has struck a relationship with another resident thereAubrey. Grant finds it mortifying and wonders if Fiona is putting on a charade, like the way she used to play jokes. Compared to the fact that Fiona might have forgotten him, imagining everything as a joke she plays is less cruel for Grant.

Despite the puzzling feeling of estrangement from his wife that Grant has to cope with, he remains steadfast, doggedly visiting everyday. He "trailed around" Fiona and Aubrey as they play cards and watch TV together. Grant feels an intense jealousy that wherever he is, "some ticking metronome in his mind" is fixed on Medowlake, on his next visit. "Sometimes he seemed to himself like a mulish boy conducting a hopeless courtship" (Munro, 295). Grant's actions and psychological activities resemble those of a young boy at the early stage of love. Munro is able to convey Grant's complex feelings through her elaborate and ingenious metaphors.

Fiona's health suffers a severe blow when Aubrey is removed from Medowlake. Grant tries different ways to cheer her up and persists to keep her company. He brings her a token of their shared past-a book about Iceland which she used to take interest in, though she never takes a single look at the book. Grant also shows great patience in his effort to jog her vanishing memories. He often reads to her in the reading room, books about chaste love and lost-and-regained fortunes. As Fiona continues to waste away, Grant takes the step to visit Aubrey's wife-Marian, in the hope that he could convince her to take Aubrey back to Medowlake. He only wishes Fiona well. If he can't cheer her up, the only thing he can do is to let go and give her the companion she wants. By doing all that he can for the good of Fiona, Grant shows himself capable of the greatest sacrifice.

\section{Conclusion}

In "The Bear Came over the Mountain”, Alice Munro presents us a stunningly depicted journey of love inter- 
woven with aging. Munro juxtaposes the past and the present and portrays ravages of aging vividly. Meanwhile, she is able to look at death straight in the eye and mock its limitations. Love triumphs in its confrontation with aging. Love knows no age or death, and it has no ending. Munro depicts love incisively as it is, complicated and ever-changing, never arriving at a certain conclusion. With their unbreakable love, Grant and Fiona keep coming back to each other despite all forces tearing them apart.

Furthermore, the title of the story also serves to enhance the theme of love against aging. The mountain symbolizes aging, and also marriage. The ravages of aging may separate them but love is a centripetal force that keeps drawing them back to the house they have built together. Further inspiration can also be drawn from Norse mythology that even when it seems like the end of world, it's not the real ending yet. Love and hope will eventually lead to salvation.

Munro's writing portrays reality but she reaches out for something deeper. Holcombe's words can best capture the spirit of Munro's writing:

Everything in Alice Munro's fiction is tinged with irony. There is the possibility of failure, hope, redemption and despair, but only the possibility, the suggestion. Nothing is ever fixed, nothing is closed off or closed down. It is in this treatment of the essential imperfection of life and its failure to conform to the quick of our fantasies, that Munro achieves greatness (Holcombe, 26).

The story tells of an evolution of love under the background of aging. Love and aging interweave and collide with each other to generate the great theme of the story-love evolves with time and it will finally defeat aging.

\section{Funding}

The paper is supported by "the Fundamental Research Funds for the Central Universities" (No: SWU1409317) and "the Specially Commissioned Research Funds of the Chongqing Federation of Social Science Circles" (No: 2014TBWT02-2).

\section{References}

Bosmans, J. (2013). Alice Munro Wins Nobel Prize in Literature. New York Times.

Chowdhury, M. (2013). Family Bond and Traumatic Pathology in Alice Munro's “The Bear Came over the Mountain”. Stamford Journal of English, 6, 103-113. http://dx.doi.org/10.3329/sje.v6i0.13906

Drainie, B. (2001). Review of “Hateship, Friendship, Courtship, Loveship, Marriage”. Quill and Quire.

Heble, A. (1994). The Tumble of Reason: Alice Munro's Discourse of Absence. Toronto: University of Toronto Press.

Holcombe, G. (2013). Alice Munro, Master of Short Stories. English World.

Lin, Y. Z. (2006). The Multiple Themes of Alice Munro’s Short Stories. A Review of the World Literature, 2, 267.

Martin, W. R. (1987). Alice Munro: Paradox and Parallel. Edmonton: The University of Alberta Press.

Mazur, C., \& Cathy, M. (2007). Alice Munro: An Annotated Bibliography of Works and Criticism. Maryland: Scarecrow Press.

Munro, A. (1989). The Bear Came over the Mountain. Hateship, Friendship, Courtship, Loveship, Marriage. Toronto: McClelland and Stewart.

Munro, A. (1996). Selected Stories. New York: Vintage.

Wood, J. (2013). Alice Munro, Our Chekhov. The New Yorker. 